\title{
Organization of Contents in Intended Junior Secondary Science Curriculum of Bangladesh: An Explorative Study
}

\author{
Kalyani Bain ${ }^{1}$, Mohammad Nure Alam Siddique ${ }^{2 *}$ \\ ${ }^{1}$ Institute of Education and Research, Khulna University, Khulna, Bangladesh, ${ }^{2}$ Institute of Education and Research, University of Dhaka, Bangladesh
}

*Corresponding Author: siddique.mna@du.ac.bd

\section{ABSTRACT}

This study explored the organization of contents in the junior secondary science curriculum of Bangladesh. The research questions of this study focus on how science content is sequenced and integrated in the intended curriculum. Document analysis within a qualitative approach has been followed to conduct this study. Both junior secondary science curriculum and textbooks have been analyzed to address the research questions. This study finds that the current science curriculum at the junior secondary level is not well-organized in terms of sequencing and integration. No principle of sequencing content is followed in most cases. It is noted that in the case of intergrades vertical sequencing, "spiral sequencing" is partially followed in a few cases. This study also finds that the current science curriculum does not integrate the content adequately. Intradisciplinary integration, i.e. integrating different subdisciplines of science, has been tried but the level of integration is not adequate rather it is very low. This study recommends that curriculum developers make efforts to make the content better organized in both curriculum and textbooks by following the principles of sequencing and integration.

KEY WORDS: science curriculum; curriculum content; organization of content; sequence; integration

\section{INTRODUCTION}

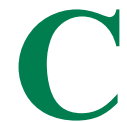

ontent is one of the four main elements of a curriculum along with objectives, methods, and evaluation. Organization of content in the curriculum is considered very important to achieve the stated goals and objectives of curriculum (Edith Cowan University, 2001) and it should be done in a manner that content does not seem to be segmented (Ehsan, 1997). Links ought to be established across learning areas whenever it is possible and practicable to do so as the University of Alabama's Center for Communication and Educational Technology asserts that this approach makes a positive impact on the achievement of students (Alberta Education, 2007). In a similar way, the Education Bureau of Hong Kong (2016) has highlighted the importance of appropriate and logically sequenced content and has described it as one of the important aspects of effective and successful learning. Malamed (2016) and Friedlander (2014) both asserted that a meaningful logical sequence helps students to comprehend and retain the content better.

Fensham (1985) argued that two competing aims of science education are dominant in science curricula; they are preparing specialist manpower and scientifically literate citizenry. In Bangladesh, a new curriculum was finalized in 2012 and implemented in 2013. The junior secondary science curriculum (i.e. Grades six-eight) aimed at "familiarizing students with modern concepts of science and scientific process to educate them with advanced science education (National Curriculum and Textbook Board [NCTB], 2012. p. 25, translated by authors)." The curriculum also aimed at providing "the foundation for pursuing science education at a higher level" (p. 25, translated by authors). It is clearly evident that the curriculum aims at preparing students for higher study to become science professionals. One the other hand, the curriculum also set objectives such as:

- $\quad$ To acquire necessary life skills and attitude for ensuring personal and social security and for overcoming adverse life situation by practicing science

- To become scientifically tempered, rational, and free of superstitions (NCTB, 2012. p. 26, translated by authors).

These objectives suggest that the curriculum also aimed at developing scientifically literate citizens. Therefore, it can be said that the current junior secondary science curriculum has tried to balance the two competing aims of science education.

Scientifically literate students are expected to grasp the broad integrating ideas of science that are necessary to understand and explain the scientific phenomena (organization for economic cooperation and development [OECD], 2003). However, our experience suggests that students in Bangladesh have a discrete understanding of nature and natural phenomena. For example, we have seen that undergraduate science students have an excellent understanding of the biological process involved in the digestion of the consumed food, but they fail to explain chemical process involved in producing energy in our body. Then the questions arise: Why do students fail to have an integrated and holistic understanding of science concepts? Is it anyway linked with how science content is 
organized in the curriculum? With these questions in our mind we explored the organization of content in the existing junior secondary science curriculum of Bangladesh. According to Ehsan (1997), after implementing a new curriculum, it needs to be reviewed, analyzed, and evaluated. Curriculum analysis and review is one key to improving the quality of education as it sets the groundwork for the further development by analyzing the current situation (National Council for Curriculum and Assessment, 2005). At present, it has been planned that the curriculum will be revised to include the junior secondary grades of six, seven, and eight in the compulsory primary education. This study aims to inform curriculum authority, curriculum developers, textbook writers, secondary science teachers, and other stakeholders about the organization of content in junior secondary science curriculum so that necessary actions can be taken for improving organization of content in the future curriculum.

This article reports partial findings of a larger study. The purpose of the larger study was to explore the organization of contents in current junior secondary science curriculum of Bangladesh. Specifically, the study aimed to find out how science contents are sequenced and integrated in intended curriculum as well as to explore how teacher's classroom practice is influenced by their views and understanding on different aspects of organization of contents. However, considering the word limit for the article, we present the answers of two research questions that focus on the organization of science content in the intended curriculum. The research questions are:

1. How is science content sequenced in the intended junior secondary curriculum?

2. How is science content integrated within the discipline and with other disciplines?

Intended curriculum in this study includes curriculum document and science textbooks for grade six, grade seven, and grade eight published by the NCTB.

\section{LITERATURE REVIEW}

We can consider that curriculum has three main forms, tiers or levels - intended, implemented, and attained curriculum. The formal intended curriculum is the most common idea of curriculum and it comprises the formal statements of rationale, aims, intended list of content or concepts to be known, or competencies or skills to be mastered in programs of study and demonstrated in assessment (Gilbert, 2012). The intended or specified curriculum has a focus on the aims and concepts of what is to be taught, that is, the curriculum which is planned and expressed through the curriculum framework and other formal documents (Gilbert, 2012). According to Porter and Smithson (2001), the intended curriculum refers to such policy tools as curriculum standards, frameworks, or guidelines that outline what teachers are expected to deliver.

As stated, content is one of the four main elements of a curriculum along with objectives, methods, and evaluation (Nicholls and Nicholls, 1988, as cited in Edith Cowan
University, 2001). Organization of content (architectonics) in a curriculum is an important part of any curriculum. The two most important aspects of organization of content in curriculum are (Print, 1993; Ehsan, 1997):

- Sequence of curriculum content

- Scope of curriculum content.

\section{Sequence of Curriculum Contents}

Ehsan (1997) referred to the sequence of curriculum as the vertical organization of content. Print (1993) and Edith Cowan University (2001) defined the sequence as the order in which content is presented to learners. Conventionally, it has been preferable that content should be sequenced by following logical approach (Edith Cowan University, 2001). The principles of sequencing content described by Print (1993 as cited in Edith Cowan University, 2001) are: Simple to complex, prerequisite learning, whole to part, and chronology. These four principles have become increasingly acceptable as the criteria for sequencing contents.

If the sequence of content involves revisiting key concepts multiple times for further development of the concepts, it is called spiral sequencing (Figure 1). Spiral sequencing is based on Bruner's (1960) learning theory (Johnston, 2012; Rhalmi, 2011).

Based on Bruner's (1960) work, Johnston (2012) described the following three key features of spiral sequencing:

1. The student revisits a topic, theme, or subject several times throughout their school career.

2. The complexity of the topic or theme increases with each revisit.

3. New learning has a relationship with old learning and is put in context with the old information.

\section{Scope of Curriculum Content}

The term scope refers to the breadth and depth of content within the curriculum at any one time. Sometimes scope is referred to as horizontal organization or "integration" (Edith Cowan University, 2001; based on Print, 1993). Print (1993) refers to integration as one of the guiding concepts that is helpful in determining scope. In this study, only integration has been studied as the scope of curriculum contents.

Integration can generally be defined as a curriculum approach that purposefully draws together knowledge, skills, attitudes, and values from within or across subject areas to develop a more powerful understanding of key ideas (Alberta Education, 2007). The New Zealand Ministry of Education (Fraser, 2010) describes integration as a broad education that makes links within and across learning areas. In its simplest conception, integration is about making connections (Drake and Burns, 2004). Curriculum integration can be of different types and approaches. It is shown in the following continuum (Figure 2).

Alberta Education (2007) and Drake and Burns (2004) describe intradisciplinary and multidisciplinary integration as following. 


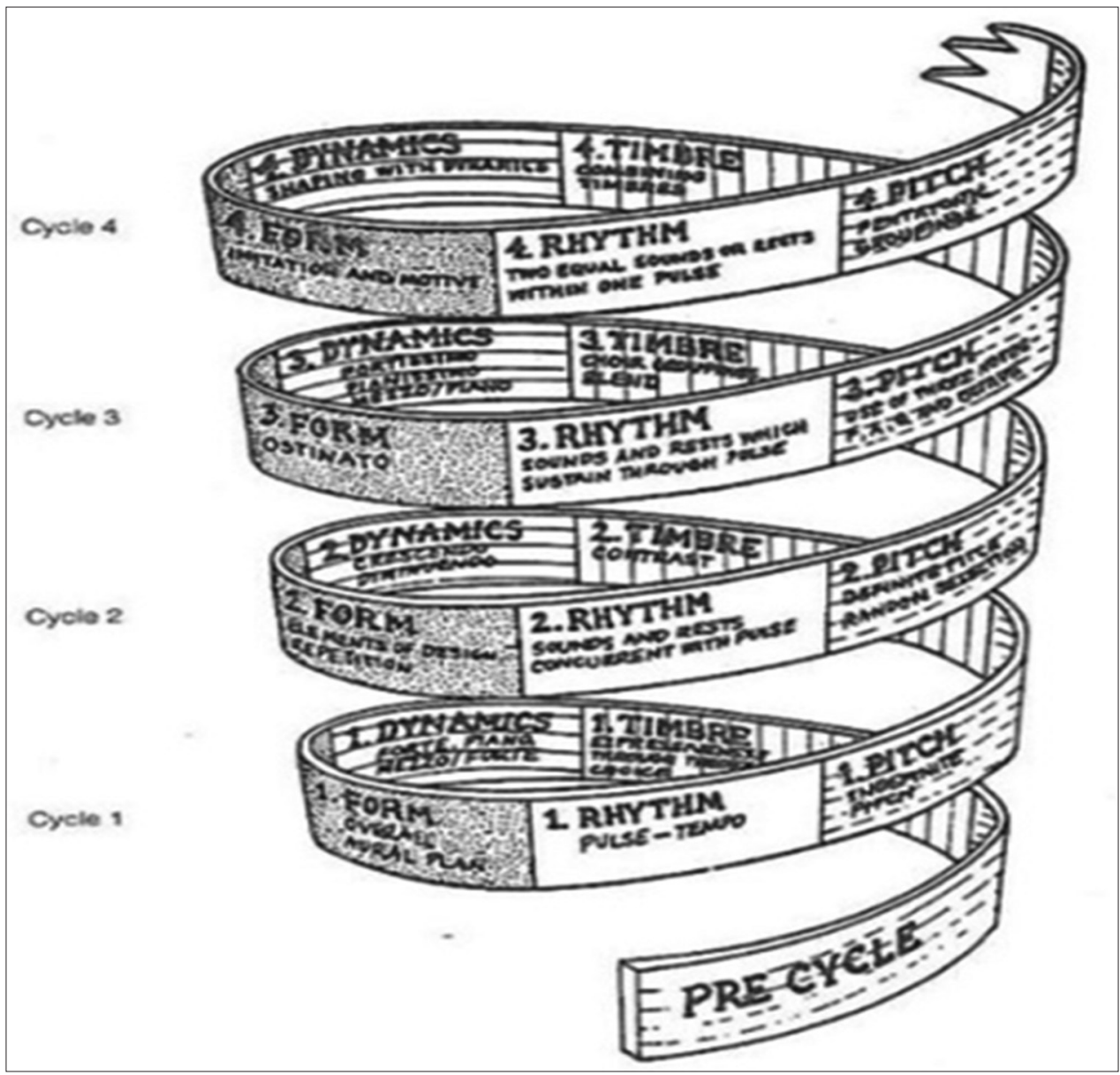

Figure 1: A curriculum concept spiral from the Manhattanville Music Curriculum Project (Edith Cowan University, 2001. p. 70-71)

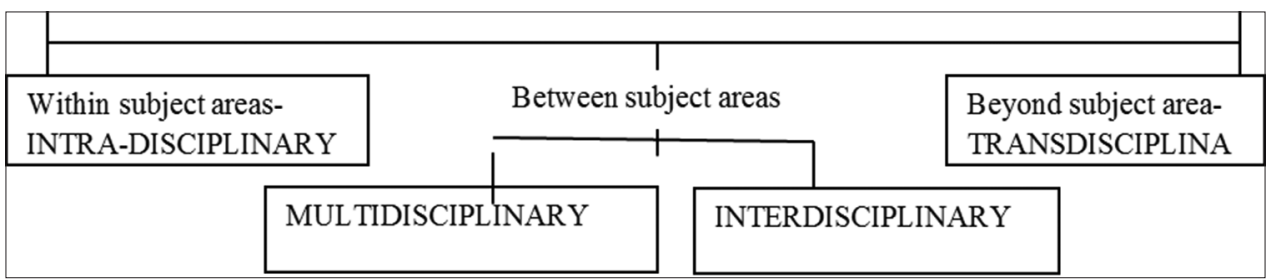

Figure 2: Curriculum integration continuum (Manitoba Education and Training, 1997 as cited in Alberta Education, 2007)

\section{Intradisciplinary}

Content from multiple subdisciplines within a discipline (in case of science discipline contents from biology, chemistry, physics, astronomy, environmental science, health, etc.,) are integrated to help students obtain a more comprehensive understanding.

\section{Multidisciplinary}

Content from multiple disciplines are organized around a theme. The theme then addresses learning outcomes from multiple disciplines including science (Figure 3).

\section{METHODOLOGY}

Creswell (2012) asserted that qualitative research is the most suitable approach for exploring and developing a detailed understanding of a central phenomenon. A qualitative approach was taken for this study since as it aimed to explore and get a detailed understanding of organization of content in the intended junior secondary science curriculum, which was the central phenomenon of the study.

Data have been collected from curriculum documents and textbooks. Textbooks along with the curriculum documents have been used because textbooks are the de facto curriculum in Bangladesh (Siddique, 2007) since the NCTB develops and publishes a single textbook for each of the subjects. The existing science curriculum for junior secondary level selected parts of the textbook for grades six, seven, and eight were used as the source of data since they are rich in information that are needed to answer the research questions of this study. The selection of these documents is in line with arguments by 
Patton (1990) that when information rich cases are selected for study in depth, purposeful sampling can be powerful and logical. Details of science curriculum and textbooks used as data source are as follows:

a. National Curriculum and Textbook Board (NCTB). (2012). National Curriculum 2012-Secondary Science (in Bengali). Dhaka: NCTB.

b. Tapan, S., Rahman, S., Haider, S.M., Jahanara, Q.A., Rahman, S.M.H., Siddique, M.N.A., Khaleque, M.A., \& Ahmed, G.A. (2016a). Science: Class Six. Dhaka: National Curriculum and Textbook Board.

c. Tapan, S., Rahman, S., Haider, S.M., Jahanara, Q.A., Rahman, S.M.H., Siddique, M.N.A., Khaleque, M.A., \& Ahmed, G.A. (2016b). Science: Class Seven. Dhaka: National Curriculum and Textbook Board.

d. Tapan, S., Rahman, S., Haider, S.M., Jahanara, Q.A., Rahman, S.M.H., Siddique, M.N.A., Khaleque, M.A., \& Ahmed, G.A. (2016c). Science: Class Eight. Dhaka: National Curriculum and Textbook Board.

\section{Collection and Analysis of Data}

Bowen (2009) stated that document analysis is useful for collecting qualitative data from written documents. Hence, document analysis was used as the method to collect and analyze data from the current junior secondary science curriculum and textbooks. A checklist was used for exploring the sequence of content in the curriculum and textbooks. The four principles of sequencing content described by Print (1993 as cited in Edith Cowan University, 2001) - simple to complex, prerequisite learning, whole to part, and chronology - were used as the components of the checklist. For exploring the status of spiral sequence in the junior secondary curriculum, four key questions (KQ) were developed based on Bruner (1960) and Johnston (2012). The KQs were:

1. Does the concept appear in multiple grades (within the junior secondary grade)?

2. Has the learning from previous grade(s) on the same concept been referred in the textbook?

3. Has the learning from previous grade(s) on the same concept been used as the base of future learning?

4. Have the breadth and complexity of the concept been increased from the previous grade?

The decision about whether content was spirally sequenced or not was determined based on the responses against the KQs (Table 1).

For exploring how science content is integrated within the discipline and with other disciplines the following rubric was used. The rubric was prepared based on Alberta Education (2007) and Drake and Burns (2004) (Figure 4).

For summing up the existing situation of integration in the junior secondary science curriculum, a continuum was used which has "discrete factual content" and "completely integrated content" as the two ends of it (Figure 5).

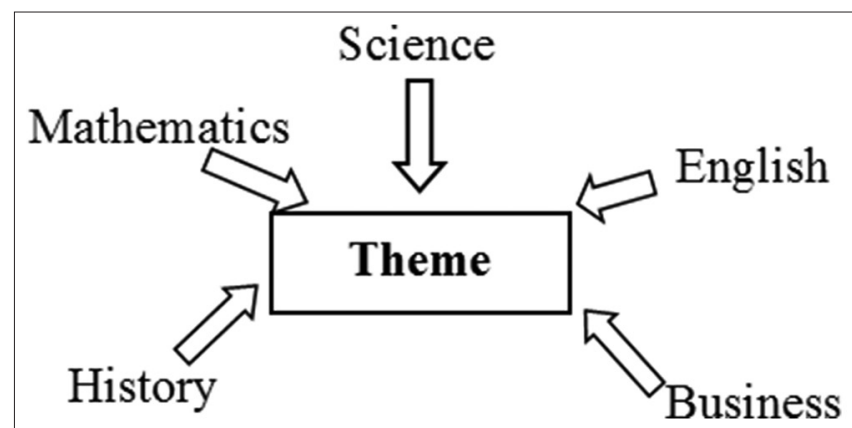

Figure 3: Multidisciplinary integration

\begin{tabular}{|c|c|}
\hline $\begin{array}{l}\text { Level of } \\
\text { integration }\end{array}$ & Explanation \\
\hline Level 1 & Discrete factual information \\
\hline Level 2 & Confined to one subdiscipline of science \\
\hline Level 3 & $\begin{array}{l}\text { Integrating/linking among multiple subdisciplines of } \\
\text { science, but not adequately }\end{array}$ \\
\hline Level 4 & $\begin{array}{l}\text { Linking among multiple subdisciplines of science and } \\
\text { for comprehensive understanding level of integration is } \\
\text { adequate }\end{array}$ \\
\hline Level 5 & $\begin{array}{l}\text { Integrating among different subdisciplines of science } \\
\text { and integrating science with other disciplines but not } \\
\text { adequately }\end{array}$ \\
\hline Level 6 & $\begin{array}{l}\text { Completely theme/concept based; integrating among } \\
\text { different subdisciplines of science and integrating Science } \\
\text { with other disciplines adequately for total comprehensive } \\
\text { understanding }\end{array}$ \\
\hline
\end{tabular}

Figure 4: Rubric for integration

\begin{tabular}{|l|l|}
\hline$\longleftrightarrow \begin{array}{l}\text { Discrete } \\
\text { factual } \\
\text { content }\end{array}$ & $\begin{array}{l}\text { Completely } \\
\text { integrated } \\
\text { content }\end{array}$ \\
\hline
\end{tabular}

Figure 5: Discrete factual content-completely integrated content continuum

Table 1: Decision on spiral sequence based on response against KQs

\begin{tabular}{ll}
\hline Type of response & Decision \\
\hline Yes against all 4 KQs & Truly spirally sequenced \\
Yes against most of the KQs & Spirally sequenced \\
Yes against 2 KQs and no against 2 KQs & Partially spirally sequenced \\
No against most of the KQs & Not spirally sequenced \\
No against all 4 KQs & Not spirally sequenced at all \\
\hline KQ: Key questions &
\end{tabular}

\section{Findings}

In this study, the dimensions of sequence of content explored were: sequence of content within a chapter, sequence among chapters within a grade, vertical sequence of content from one grade to another (inter-grades sequence), and spiral sequence.

No principle is followed in most cases when sequencing contents within a chapter from the document analysis, it was found that in most cases no principle of sequencing of content 


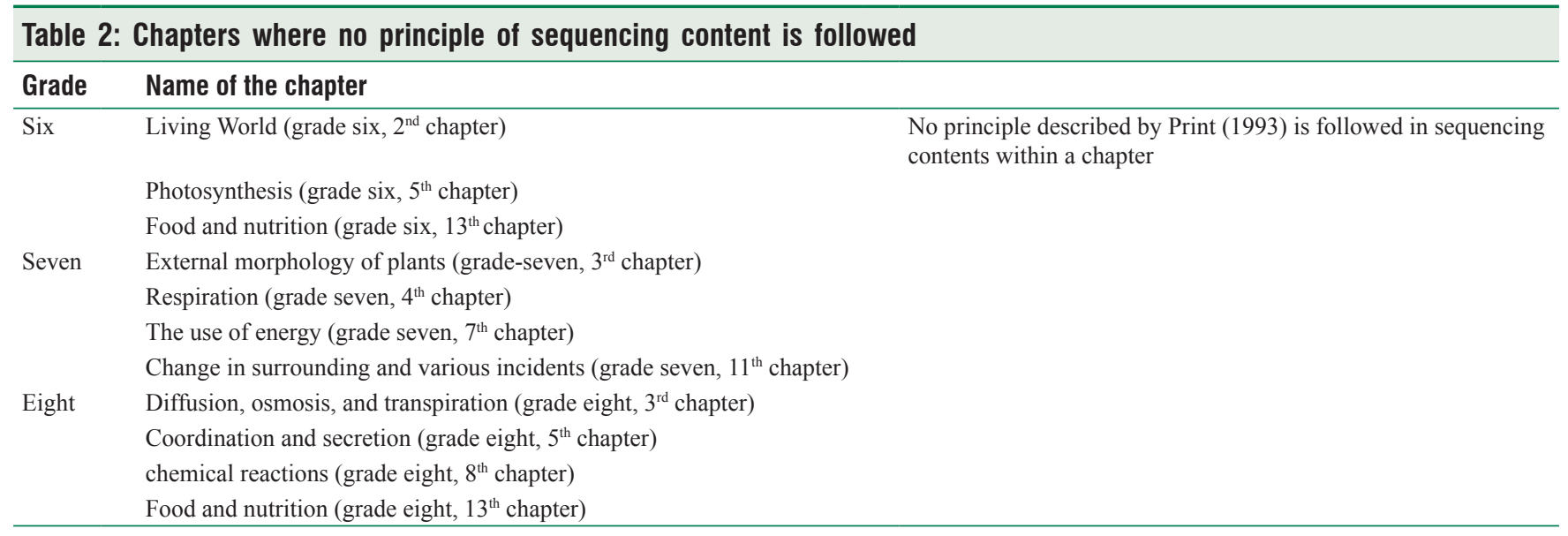

as described by Print (1993) was followed within a chapter in the explored parts of the junior secondary science curriculum. In addition, in only a few cases, were some of the principles followed or partially followed.

No reflection of any principle of sequencing content described by Print (1993) was found in the following chapters (Table 2).

For example, the chapter named "external morphology of plants" (grade Seven, $3^{\text {rd }}$ chapter) has the teaching sequence:

- Lesson - 1: Modifications of main root

- Lessons - 2-4: Modified adventitious roots

- Lessons - 5-7: Modified stems

- $\quad$ Lesson - 8: Modified leaves.

This sequence does not seem to be consistent with any of the principles of sequencing content as described by Print (1993). However, this content could be sequenced by the principle "whole to part" where modifications in plants as a whole is presented first, and then, modification of different parts of the plant in detail is presented (Table 3 ).

It has been found that in only a few cases were some of the principles followed in sequencing content within a chapter. One of the sequences "whole to part" was followed quite explicitly in the chapters named "external morphology of plants" (grade six, $4^{\text {th }}$ chapter), "digestive system and blood circulation system" (grade seven, $5^{\text {th }}$ chapter), "lower organisms" (grade Seven, $1^{\text {st }}$ chapter), and "classification of animal kingdom" (grade eight, $1^{\text {st }}$ chapter). In these chapters, content was presented as a broad theme first, and then, different parts of the theme were discussed in detail. For example, in the chapter "external morphology of plants" (grade six, $4^{\text {th }}$ chapter), the morphology of an ideal flowering plant was presented first and then various aspects of different parts (i.e. root, stem, leaf) of it were discussed in detail (Table 4).

In some cases, principles were followed partially. In the chapter named "the structure of atom" (grade eight, $6^{\text {th }}$ chapter), some parts of it reflected "prerequisite learning" and "whole to part" as the principles of sequencing content. In the beginning of the chapter, electrons and isotopes are discussed and when
Table 3: Probable sequence of content if "whole to part" principle is followed

\begin{tabular}{ll}
\hline Whole & $\begin{array}{l}\text { Part }- \text { where the modification } \\
\text { takes place }\end{array}$ \\
\hline $\begin{array}{l}\text { Modifications in plants } \\
\text { Purpose/nature of modification }\end{array}$ & Modified roots \\
& $\begin{array}{l}\text { Modified stems } \\
\text { Modified leaves }\end{array}$ \\
\hline
\end{tabular}

\begin{tabular}{|c|c|c|}
\hline Whole & Part & $\begin{array}{l}\text { Principle of } \\
\text { sequencing }\end{array}$ \\
\hline $\begin{array}{l}\text { External } \\
\text { morphology of a } \\
\text { flowering plant } \\
\text { including the } \\
\text { example of chili } \\
\text { plant (Capsicum } \\
\text { frutescens) }\end{array}$ & $\begin{array}{l}\text { Stem } \\
\text { - Different parts of a stem } \\
\text { - Classifications of stem } \\
\text { - Role of stem } \\
\text { Leaf } \\
\text { - Different parts of a leaf } \\
\text { - General role of leaves } \\
\text { - Classifications of leaves } \\
\text { Importance/necessity of root, } \\
\text { stem and leaf in human life, } \\
\text { empathy toward plant and animal }\end{array}$ & Whole to Part \\
\hline
\end{tabular}

electron configuration and use of isotopes are discussed in the later in the chapter, these topics build upon the earlier material presented. Similarly, electron configuration material is referred to again when properties of elements are discussed. Consistent 
with the principle "whole to part," the atom is discussed as a whole and later the electron is discussed in detail. However, this sequencing is not reflected in the entire chapter.

\section{Most of the Chapters within a Grade are Discrete from} Each Other and No Pattern of Sequencing Them is Found In the document analysis, this study tried to uncover if there was any pattern of sequence among the chapters within a grade. The junior secondary science curriculum included content from biological science, physical science (physics and chemistry), earth and space science, and environmental science. Some sort of a general pattern was found in the science curriculum and textbooks. Chapters on biological science were placed at the beginning, chapters on physical science (physics and chemistry) were in the middle and then at the end, chapter(s) on environmental science was included. Other than this, no pattern of sequencing the chapters within a grade was found and most the chapters seemed to be discrete from each other. Table 5 presents the detailed analysis on sequencing among the chapters of the Science curriculum of grade eight.
From Table 5, it is clear that even chapters that belong to same subdiscipline of science were discrete from each other in most cases. For example, at grade seven there are five chapters on biology; these chapters are not linked to each other as illustrated in Table 6.

Each of the above-mentioned chapters has a different focus (theme). There is no direct linking among them nor do they present a holistic view of the living world. As a result, no pattern of sequence among these chapters was found.

\section{Sometimes Principles are Followed and Sometimes They} are Not when Sequencing Contents Vertically from one Grade to Another (Intergrades Sequence)

Sometimes principles of sequencing content described by Print (1993 as cited in Edith Cowan University, 2001) were followed in intergrade vertical sequence in the explored parts of the junior secondary science curriculum while sometimes none of these principles were followed. In the cases presented in Table 7, some of the principles were followed and so the sequence seems logical.

Table 5: Sequence of chapters within grade eight

\begin{tabular}{|c|c|c|c|}
\hline \multicolumn{4}{|l|}{ Grade eight } \\
\hline $\begin{array}{l}\text { Subdiscipline of } \\
\text { science }\end{array}$ & Chapter no and name & Focus of the chapter(s) & Comments on organization \\
\hline Biology (mainly) & $\begin{array}{l}\text { 1. Classification of animal kingdom } \\
\text { 2. Growth and heredity of living organism } \\
\text { 3. Diffusion, osmosis and absorption } \\
\text { 4. Reproduction in plants } \\
\text { 5. Coordination and secretion }\end{array}$ & $\begin{array}{l}\text { Classification } \\
\text { Process and systems in living beings }\end{array}$ & $\begin{array}{l}\text { Different chapters have got different } \\
\text { focus (theme); no direct linking has been } \\
\text { found. No pattern of sequence (among these } \\
\text { chapters) is found }\end{array}$ \\
\hline \multirow[t]{6}{*}{ Physical science } & 6. The structure of atoms & $\begin{array}{l}\text { Atom, atomic, and mass number, } \\
\text { isotope, distribution of electrons, ions }\end{array}$ & $\begin{array}{l}\text { Each chapter is discrete from each other in } \\
\text { most cases and no pattern of sequence (among }\end{array}$ \\
\hline & 7. The earth and gravitation & $\begin{array}{l}\text { Gravitation, gravity, acceleration due } \\
\text { to gravity, mass and weight }\end{array}$ & $\begin{array}{l}\text { these chapters) is found } \\
\text { Dry cell as a source of electrical energy }\end{array}$ \\
\hline & 8. Chemical reaction & $\begin{array}{l}\text { Classification and contributions of } \\
\text { chemical reaction in our life, energy } \\
\text { transformation }\end{array}$ & $\begin{array}{l}\text { and electrolysis in discussed in chapter } 8 . \\
\text { Electricity is then described in detail in } \\
\text { chapter } 9\end{array}$ \\
\hline & 9. Electric circuits and current electricity & $\begin{array}{l}\text { AC, DC flow; resistance, voltage } \\
\text { difference, circuit, ammeter, } \\
\text { voltmeter }\end{array}$ & \multirow{3}{*}{$\begin{array}{l}\text { In chapter } 8 \text { when explaining transformation } \\
\text { of energy through chemical reaction, reaction } \\
\text { between alkaline substance and acidic } \\
\text { substance is discussed. And in chapter 10, } \\
\text { properties of acid and base (alkali) and reaction } \\
\text { between them are presented in detail. }\end{array}$} \\
\hline & 10. Acid, base and salt & $\begin{array}{l}\text { Properties and use of acid, base, salt } \\
\text { and neutral substances (including } \\
\text { reactions) }\end{array}$ & \\
\hline & 11. Light & $\begin{array}{l}\text { Refraction, total internal reflection, } \\
\text { how optical fibers, magnifying glass, } \\
\text { spectacles, camera, and eye work }\end{array}$ & \\
\hline $\begin{array}{l}\text { Earth and space } \\
\text { science }\end{array}$ & 12. The outer space and satellites & $\begin{array}{l}\text { Outer space and the universe, natural } \\
\text { and artificial satellite }\end{array}$ & Discrete from others \\
\hline Biology & 13. Food and nutrition & $\begin{array}{l}\text { Food, nutrition, nutrition value, and } \\
\text { prevention of malnutrition-related } \\
\text { diseases }\end{array}$ & $\begin{array}{l}\text { This chapter is quite discrete from the others. } \\
\text { Although sometimes chemical reactions (which } \\
\text { involve presence of different food components) } \\
\text { are included, they are not linked to the } \\
\text { chapter } 8 \text { (chemical reaction) }\end{array}$ \\
\hline $\begin{array}{l}\text { Environmental } \\
\text { science }\end{array}$ & 14. Environment and ecosystem & $\begin{array}{l}\text { Environmental components and } \\
\text { types, food chain, food web, } \\
\text { flow of energy in the ecosystem, } \\
\text { role of ecosystem in maintaining } \\
\text { environmental balance }\end{array}$ & $\begin{array}{l}\text { This chapter seems to be discrete. Though it is } \\
\text { placed at the end of the textbook, any link with } \\
\text { other chapters is hardly found }\end{array}$ \\
\hline
\end{tabular}


For example, "morphology of plants" is included in both grades six and seven textbooks. In the grade six textbook, morphology, i.e., different parts (root, stems, and leaves) of an ideal flowering plant are presented and discussed in detail. On the other hand, various types of modification of different parts (root, stems, and leaves) of a plant are presented in the grade seven textbook. The content of grade seven are comparatively more complex than that of grade six. Hence, the principle of "simple to complex" was followed from one grade to the next. In the cases presented in the Table 8, none of the principles were found and so the sequence does not seem logical.

For example, in the curriculum photosynthesis ( $5^{\text {th }}$ chapter), respiration $\left(4^{\text {th }}\right.$ chapter $)$ and diffusion, osmosis, and absorption $\left(3^{\text {rd }}\right.$ chapter) are included in grade six, grade seven, and grade eight, respectively. This sequence does not look logical as absorption of water and minerals takes place and they are transported to leaves first; then photosynthesis happens; finally, using the food produced in the photosynthesis energy is produced in the respiration process. Therefore, it would be more logical if the content was sequenced by following "chronology" principle; see Table 9 for what this sequence could be like.

\section{"Spiral Sequencing" is Followed in a Few Cases but Only Partially}

Intergrade vertical sequence was not spirally sequenced in most cases in the explored parts of the junior secondary science curriculum. "Spiral sequencing" was followed in a few cases but only partially. As mentioned earlier, spiral sequencing involves revisiting key concepts multiple times and using learning from the previous grades as the base for further development of the concepts. None of the explored parts was truly spirally sequenced as none of them have affirmative responses against all of the KQs of spiral sequencing mentioned in the methodology. Some of them are only partially spiral sequenced (as they have affirmative responses against some of the KQs) while some of them are not spirally sequenced at all (as they have negative responses against most of the KQs). The status of the explored parts of the curriculum in terms of spiral sequencing is shown in Table 10.

Let us consider an example, "food and nutrition" as a concept is included in grade six and grade eight. The responses against the KQs of spiral sequencing are shown in Table 11.

Hence, it was found that "food and nutrition" has affirmative responses against KQs 1 and 4 and negative response against

Table 6: Five chapters of biology subdiscipline in grade seven

\begin{tabular}{llll}
\hline Subdiscipline of science & Chapter no & Chapter name & Focus of the chapter(s) \\
\hline Biology & 1 & Lower organisms & Discussion on structure and characteristics of living beings \\
& 2 & Cellular organization of plants and animals & \\
3 & External morphology of plants & Biological process and system \\
4 & Respiration & \\
5 & Digestive system and blood circulation system & \\
\hline
\end{tabular}

Table 7: Principles of sequencing contents in case of vertical sequence

\begin{tabular}{llll}
\hline Grade six & Grade seven & Grade eight & Principles being followed \\
\hline $\begin{array}{l}\text { Morphology of plants } \\
\text { Food and Nutrition }\end{array}$ & External morphology of plants & & Simple to complex \\
& Structure of matter (partial) & Food and nutrition & Simple to complex \\
& The structure of atoms & $\begin{array}{l}\text { Simple to complex (partially) pre-requisite } \\
\text { learning (partially) } \\
\end{array}$ & Simple to complex \\
\hline
\end{tabular}

\section{Table 8: Vertical sequence with no principle of sequencing contents}

\begin{tabular}{|c|c|c|c|}
\hline Grade six & Grade seven & Grade eight & Principles being followed \\
\hline Photosynthesis & Respiration & $\begin{array}{l}\text { Diffusion, osmosis and } \\
\text { absorption }\end{array}$ & $\longrightarrow$ \\
\hline Living world & Lower organisms & $\begin{array}{l}\text { Classification of animal } \\
\text { kingdom }\end{array}$ & \\
\hline $\begin{array}{l}\text { Let us know motion, force and simple } \\
\text { machines (partially, very little) }\end{array}$ & Use of energy & & No principle described by print is found \\
\hline Sensory organs (partially, very little) & & Coordination and secretion & \\
\hline & $\begin{array}{l}\text { Digestive system and } \\
\text { blood circulation system }\end{array}$ & & $\begin{array}{l}\text { Not applicable (as it appears in only one grade } \\
\text { within junior secondary level) }\end{array}$ \\
\hline
\end{tabular}


2 and 3 . Hence, it was considered as only partially spiral sequenced.

On the other hand, for example "energy" as a concept is included in grade six and grade seven. In grade six, energy is included in the chapters named "let us know motion" and "force and simple machines", and in grade seven there is a chapter named "use of energy." In this case, the responses against the KQs of spiral sequencing are shown in Table 12.

Therefore, it was found that "energy" as a concept has negative responses against KQs 2, 3, and 4, so it was considered as not spirally sequenced.

Integration among multiple subdisciplines of science has been tried but level of integration is not adequate rather very low and integrating science with other disciplines is not found in any of the chapters.

As mentioned earlier, "integration" refers to a curriculum approach that purposefully draws together knowledge, skills, attitudes, and values from within or across subject areas to develop a more powerful understanding of key ideas (Alberta Education, 2007). Intradisciplinary and multidisciplinary approaches of curriculum integration in the junior secondary science curriculum were explored in this study. In most of the chapters examined from the junior secondary science curriculum and textbooks, it is found that linking among multiple subdisciplines of science was tried but the level of integration is not adequate rather it was very low (which indicates level 3 of analytical rubric). As for the other chapters, either they are confined to one subdiscipline of science (level 2) or involve integrating/linking among multiple subdisciplines of science adequately (level 4). It was found that linking/integrating science with other disciplines such as

\begin{tabular}{lll}
\hline \multicolumn{3}{l}{$\begin{array}{l}\text { Table 9: Probable vertical sequence of content if } \\
\text { "chronology" was followed as the principle }\end{array}$} \\
\hline Grade 6 & Grade 7 & Grade 8 \\
\hline Diffusion, osmosis, and absorption & Photosynthesis & Respiration \\
\hline
\end{tabular}

social science, humanities, mathematics, and language, was not included in any of the chapters explored in this study. The position of each chapter investigated in the integration analytical rubric is showed in the Table 13.

It is clear from the Table 13 that most of the chapters ( 8 chapters in total) belong at level-3 of the analytical rubric which indicates integrating multiple subdisciplines of science but not adequately. For example in the chapter "lower organisms" (grade seven, $1^{\text {st }}$ chapter), it tried to link microbiology with a number of various subdisciplines of science such as health science (role of virus and bacteria as pathogen for various diseases), agriculture (role of bacteria in nitrogen fixation), environmental science (role of bacteria in decomposing dead bodies and organic waste), etc. However, all of these were only mentioned in the textbook; none of the links were explored sufficiently. There was scope for doing so as it would have helped the students to understand more comprehensively. Integration within this chapter seemed to be superficial and not adequate; so it was placed at level 3 on the analytical rubric.

Some of the chapters (4 chapters in total) were assessed at level-2 of the analytical rubric which indicated being confined to one subdiscipline of science. For example, the chapter named "chemical reaction" (grade eight, $8^{\text {th }}$ chapter) was confined to chemistry only; the chapter never went beyond the topic of chemistry.

Rest four chapters were assessed at level-4 of the analytical rubric which meant integrating/linking among multiple subdisciplines of science and the level of integration was adequate. For example in the chapter named "respiration," zoology and botany were integrated when respiration in living world was discussed. Similarly, zoology and health science were integrated when common diseases of the respiratory tract were discussed. All of the mentioned content and links among the different subdisciplines of science were discussed thoroughly. Integration within this chapter seemed to be adequate; so it was placed at level 4 on the analytical rubric.

\begin{tabular}{|c|c|c|c|}
\hline Grade six & Grade seven & Grade eight & $\begin{array}{l}\text { Status in terms of spiral } \\
\text { sequencing }\end{array}$ \\
\hline Morphology of plants & External morphology of plants & & Partially spirally sequenced \\
\hline \multirow[t]{3}{*}{ Food and nutrition } & & Food and nutrition & Partially spirally sequenced \\
\hline & Structure of matter & The structure of atoms & Partially spirally sequenced \\
\hline & $\begin{array}{l}\text { Change in surrounding and various } \\
\text { incidents }\end{array}$ & Chemical reaction & Partially spirally sequenced \\
\hline Photosynthesis & Respiration & Diffusion, osmosis, and absorption & Not spirally sequenced \\
\hline Living world & Lower organisms & Classification of animal kingdom & Not spirally sequenced \\
\hline $\begin{array}{l}\text { Let us know motion, force and simple } \\
\text { machine (partially) }\end{array}$ & Use of energy & & Not spirally sequenced \\
\hline \multirow[t]{2}{*}{ Sensory organs (partially, very little) } & & Coordination and secretion & Not spirally sequenced \\
\hline & $\begin{array}{l}\text { Digestive system and blood } \\
\text { circulation system }\end{array}$ & & Not spirally sequenced \\
\hline
\end{tabular}




\begin{tabular}{lll}
\hline \multicolumn{2}{l}{$\begin{array}{l}\text { Table 11: Response against KQs in case of "food and } \\
\text { nutrition" }\end{array}$} \\
\hline No & Key question & $\begin{array}{l}\text { Response (in the case } \\
\text { of food and nutrition) }\end{array}$ \\
\hline KQ-1 & $\begin{array}{l}\text { Does the concept appear in multiple } \\
\text { grades (within junior secondary } \\
\text { grade)? }\end{array}$ & Yes \\
KQ-2 & $\begin{array}{l}\text { Has the learning from previous } \\
\text { grade (s) on the same concept been } \\
\text { referred in the textbook? }\end{array}$ & No \\
KQ-3 & $\begin{array}{l}\text { Has the learning from previous } \\
\text { grade (s) on the same concept been } \\
\text { used as the base of future learning? }\end{array}$ & No \\
KQ-4 $\quad \begin{array}{l}\text { Have the breadth and complexity of } \\
\text { the concept been increased from the } \\
\text { previous grade? }\end{array}$ & Yes \\
\hline KQ: Key question
\end{tabular}

\begin{tabular}{lll}
\hline Table & 12: Response against KQs in case of "energy" \\
\hline No & Key question & $\begin{array}{l}\text { Response (in the } \\
\text { case of energy) }\end{array}$ \\
\hline KQ-1 & $\begin{array}{l}\text { Does the concept appear in multiple } \\
\text { grades (within junior secondary grade) }\end{array}$ & Yes \\
KQ-2 & $\begin{array}{l}\text { Has the learning from previous grade (s) } \\
\text { on the same concept been referred in the } \\
\text { textbook? }\end{array}$ & No \\
KQ-3 & $\begin{array}{l}\text { Has the learning from previous grade (s) } \\
\text { on the same concept been used as the base } \\
\text { of future learning? }\end{array}$ & No \\
KQ-4 $\begin{array}{l}\text { Have the breadth and complexity of the } \\
\text { concept been increased from the previous } \\
\text { grade? }\end{array}$ & No \\
\hline
\end{tabular}

KQ: Key question

As noted earlier the linking or integrating of science with other disciplines such as social science, humanities, mathematics, and language, was not included in any of the chapters explored in this study. Nevertheless, there was scope for this type of integration (multidisciplinary) in some cases. For example, the importance of donating blood (humanities and a social responsibility-related issue) could have been included in the chapter "digestive system and blood circulation system" and the misuse of atoms and isotopes as weapons (humanities and a social responsibility-related issue) could have been included in the chapter "the structure of atom."

\section{Integration Continuum}

From Table 13, it is clear that most of the chapters belong at level 3 of the analytical rubric while only few of them belonging to level 4 or level 2. Hence, the current junior secondary science curriculum could be placed on the continuum "discrete factual content" to "completely integrated content" as seen in Figure 6.

The current junior secondary curriculum was placed almost at the middle (a little bit closer to the discrete factual content end) of the continuum because it does not reflect complete integration.
Table 13: Position of different chapters in the integration analytical rubric

\begin{tabular}{|c|c|c|}
\hline Grade & Name of the chapter & $\begin{array}{l}\text { Position } \\
\text { in the } \\
\text { integration } \\
\text { analytical } \\
\text { rubric }\end{array}$ \\
\hline \multirow[t]{4}{*}{ Six } & Living world ( $2^{\text {nd }}$ chapter $)$ & Level 3 \\
\hline & Morphology of plants ( $4^{\text {th }}$ chapter $)$ & Level 3 \\
\hline & Photosynthesis ( $5^{\text {th }}$ chapter $)$ & Level 4 \\
\hline & Food and nutrition $\left(13^{\text {th }}\right.$ chapter $)$ & Level 4 \\
\hline \multirow[t]{6}{*}{ Seven } & Lower organisms ( $1^{\text {st }}$ chapter $)$ & Level 3 \\
\hline & External morphology of plant ( $3^{\text {rd }}$ chapter) & Level 2 \\
\hline & Respiration $\left(4^{\text {th }}\right.$ chapter $)$ & Level 4 \\
\hline & $\begin{array}{l}\text { Digestive system and blood circulation } \\
\text { system }\left(5^{\text {th }} \text { chapter }\right)\end{array}$ & Level 2 \\
\hline & Use of energy ( $7^{\text {th }}$ chapter $)$ & Level 3 \\
\hline & $\begin{array}{l}\text { Change in surrounding and various } \\
\text { incidents }\left(11^{\text {th }} \text { chapter }\right)\end{array}$ & Level 3 \\
\hline \multirow[t]{6}{*}{ Eight } & Classification of animal kingdom ( $1^{\text {st }}$ chapter $)$ & Level 2 \\
\hline & Diffusion, osmosis and absorption ( $3^{\text {rd }}$ chapter) & Level 3 \\
\hline & Coordination and secretion ( $5^{\text {th }}$ chapter $)$ & Level 3 \\
\hline & The structures of atoms ( $6^{\text {th }}$ chapter $)$ & Level 3 \\
\hline & Chemical reaction ( $8^{\text {th }}$ chapter $)$ & Level 2 \\
\hline & Food and nutrition ( $13^{\text {th }}$ chapter $)$ & Level 4 \\
\hline
\end{tabular}

\section{DISCUSSION}

This study found that in most cases no principle of sequencing content as described by Print (1993) was followed within a chapter in the explored parts of the junior secondary science curriculum. In only a few cases were some of the principles followed or partially followed. It was noted, any pattern of sequencing the chapters within a grade was minimal as most the chapters seemed to be discrete from each other. In the case of intergrade vertical sequencing, some principles of sequencing content as described by Print (1993) were followed while in some cases none of them is followed. "Spiral sequencing" was attempted in only in a few cases. Therefore, it could be said that the science content in the junior secondary curriculum was not well sequenced.

Research literature acknowledges the importance of wellsequenced content and puts emphasis on this. Edith Cowan University (2001) described the principles described by Print (1993) as "logical approach" and "increasingly acceptable criteria for sequencing content." The Education Bureau of Hong Kong (2016) emphasized an appropriate and logical sequence of content and has described it as one of the important aspects of effective and successful learning. According to Malamed (2016) and Friedlander (2014) a meaningful logical sequence helps students to comprehend and retain the content better. According to Johnston (2012) spiral sequencing is beneficial as knowledge is reinforced and solidified each time the students revisit the subject matter, it allows logical progression from simplistic ideas to complicated ideas, involves activating prior knowledge, or building new learning on prior learning. He 


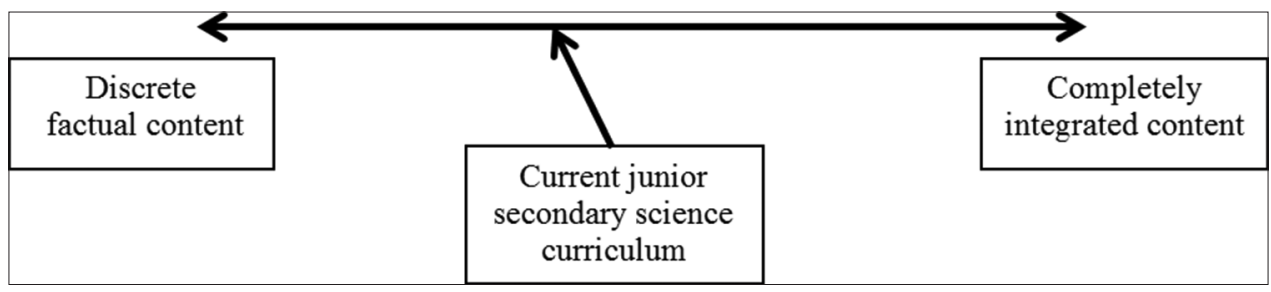

Figure 6: Position of current junior secondary science curriculum on a Discrete factual content - Completely integrated content continuum

added that spiral sequence incorporates many research based approaches from cognitive science that have been linked to improve students' performance and produce learning gains for almost all students. Spiral sequence ensures understanding of full formal concept as it involves active learning of students and use of prior experience to fit new information into the preexisting structure (Rhalmi, 2011).

This study found that in most of the chapters, linking among multiple subdisciplines of Science was tried, but the level of integration was not adequate rather it was very low. For the other chapters, either they were confined to one subdiscipline of science or involved integrating multiple subdisciplines of science adequately. This study found that integrating science with other disciplines such as social science, humanities, mathematics, and language, was not included in any of the chapters explored in this study. These finding are not in line with recent literature since recent literature considers integration as very important. According to Program for International Student Assessment's (PISA) suggestion, scientifically literate students are expected to grasp the broad integrating ideas of Science that are necessary to understand and explain the scientific phenomena (OECD, 2003). According to Alberta Education (2007), there are several benefits of curriculum integration like when curriculum is organized in a holistic way rather than in fragmented pieces, it better reflects how students' brains process information and it better reflects the real world and the way children learn at home and in the community. According to the University of Alabama's Center for Communication and Educational Technology (2005 as cited in Alberta Education, 2007), through intradisciplinary integration, teachers expect students to understand the connections between the different subdisciplines and their relationship to the real world. The University of Alabama reported a positive impact of intradisciplinary integration on students' achievement. On the other hand, the National Curriculum Board of Australia (2009) and The Curriculum Development Council of Hong Kong (2002) described multidisciplinary integration as important and explicitly emphasis this type of integration. Alberta Education (2007) described integration as important as it enables students to develop a unified view of the curriculum to broaden the context of their leaning beyond single subject areas and involves the development of key skills and understandings that transcend individuals. Since the current junior secondary science curriculum does not reflect integration adequately; it does not help or promote students' holistic learning.

\section{CONCLUSION}

The findings of this study have implications for curriculum development and teachers' practice. From this study, it was found that the content of the current junior secondary science curriculum and associated textbooks were not organized properly. If science content was organized properly in the curriculum and presented in the corresponding textbook accordingly, students would learn science in a more organized and holistic way. National Curriculum and Textbook Board in Bangladesh has been given the responsibility to prepare a holistic curriculum for newly designed primary education which is now up to grade eight. Therefore, there is a good opportunity now to develop a well-sequenced and wellintegrated science curriculum for students from grade one to grade eight. The findings of this study will help curriculum developers' effort to organize content in the next curriculum by following the principles of sequencing and integration. Then, textbook writers would need to present content in the textbook by following the same principles.

Teachers may find the findings of this study helpful for planning and conducting their teaching as it informs them about different aspects of organization of content and the importance of them.

\section{RECOMMENDATIONS FOR FUTURE RESEARCH}

Intradisciplinary and multidisciplinary integration were explored in this study. There are other two types of integration: Interdisciplinary integration and transdisciplinary integration. The existing status as well as scope of these types of integrations in the Bangladesh context should be studied in the future research. A new framework (i.e., four KQs of spiral sequence, rubric, and continuum for determining the level of integration) was used in this study. Future research could be done to determine the effectiveness of this framework.

\section{REFERENCES}

Alberta Education. (2007). Primary Programs Framework-Curriculum Integration: Making Connections. Alberta: Alberta Education.

Bowen, G.A. (2009). Document analysis as a qualitative research method. Qualitative Research Journal, 9(2), 27-40.

Bruner, J. (1960). The Process of Education. Cambridge, MA: The President and Fellows of Harvard College.

Drake, S.M., \& Burns, R.C. (2004). Meeting Standards through Integrated Curriculum. Alexandria: Association for Supervision and Curriculum Development (ASCD). 
Creswell, J.W. (2012). Educational Research: Planning, Conducting, and Evaluating Quantitative and Qualitative Research. $4^{\text {th }}$ ed. Boston: Pearson Education Inc.

Edith Cowan University. (2001). Curriculum Theory and PracticeUnit Notes (Based on Materials Originally Developed by Professor Murray Print). Perth: Edith Cowan University.

Education Bureau-The government of the Hong Kong Special Administrative Region. (2016). Guiding Principles for Quality Textbooks. Hong Kong: Education Bureau.

Ehsan, M.A. (1997). Curriculum Development: Principle and Method. Dhaka: Chatrabondhu Library.

Fensham, P.J. (1985). Science for all: A reflective essay. Journal of Curriculum Studies, 17(4), 415-435.

Fraser, D. (2010). Curriculum Integration. Wellington: New Zealand Council for Educational Research.

Friedlander, J. (2014). Sequencing Contents. Memphis: Southwest Tennessee Community College.

Gilbert, R. (2012). Curriculum Planning in a Context of Change: A Literature Review. New Zealand: Victoria University Wellington, Department of Education and Early Childhood Development.

Johnston, H. (2012). The Spiral Curriculum. Florida: Education Partnerships, Inc. Available from: https://www.eric.ed.gov/?id=ED538282. [Last accessed on 2017 Jun 19].

Malamed, C. (2016). 10 Ways to Organize Instructional Contents. Available from: http://www.theelearningcoach.com/elearning_design/how-toorganize-content. [Last accessed on 2017 Jun 19].

National Council for Curriculum and Assessment (NCCA). (2005). Primary curriculum Review Phase 1. Dublin: NCCA.

National Curriculum and Textbook Board (NCTB). (2012). National Curriculum 2012-Secondary Science (in Bengali). Dhaka: NCTB.

National Curriculum Board. (2009). Shape of the Australian Curriculum: Science. Melbourne: National Curriculum Board.

Nicholls, A., \& Nicholls, S.H. (1978). Developing a Curriculum: A Practical Guide. London: George Allen and Unwin.

Organization for Economic Co-operation and Development, OECD. (2003). Literacy Skills for the World of Tomorrow: Further Results from PISA 2000. Paris: OECD.

Patton, M.Q. (1990). Qualitative Evaluation and Research Methods. $2^{\text {nd }}$ ed. Newbury Park: Sage Publications.

Porter, A.C., \& Smithson, J.L. (2001). Defining, Developing and Using Curriculum Indicators. Philadelphia: Consortium for Policy Research in Education, University of Pennsylvania.

Print, M. (1993). Curriculum Development and Design. $2^{\text {nd }}$ ed. St. Leonards: Allen \& Unwin.

Rhalmi, M. (2011). Implication of Bruner's Learning Theory on Teaching. Available from: http://www.myenglishpages.com/articles learningtheories. [Last accessed on 2017 Jun 19].

Siddique, M.N.A. (2007). Existing and Proposed Science Curricula of Grades $I X-X$. In: Bangladesh: A Comparative Study. (Master's Thesis, Faculty of Education, Monash University.

The Curriculum Development Council. (2002). Science Education-Key Learning Area Curriculum Guide (Primary 1-Secondary 3). Kowloon: Education Department. 